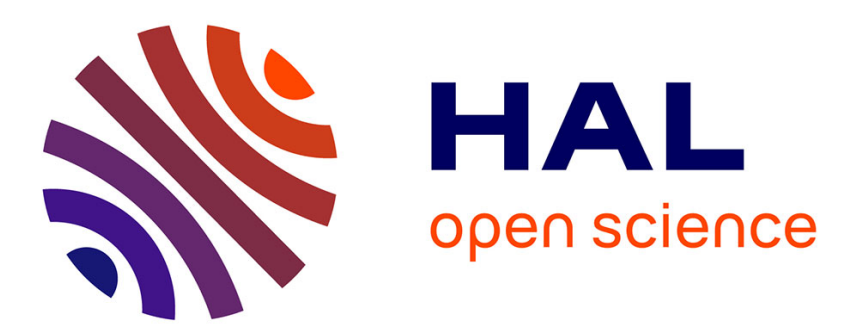

\title{
Partitioning of Heavy Metals in Municipal Solid Waste Pyrolysis, Gasification, and Incineration
}

\author{
Jun Dong, Yong Chi, Yuanjun Tang, Mingjiang Ni, Ange Nzihou, Elsa \\ Weiss-Hortala, Qunxing Huang
}

\section{- To cite this version:}

Jun Dong, Yong Chi, Yuanjun Tang, Mingjiang Ni, Ange Nzihou, et al.. Partitioning of Heavy Metals in Municipal Solid Waste Pyrolysis, Gasification, and Incineration. Energy \& Fuels, 2015, 29 (11), pp.7516-7525. 10.1021/acs.energyfuels.5b01918 . hal-01632390

\section{HAL Id: hal-01632390 https://hal.science/hal-01632390}

Submitted on 2 May 2018

HAL is a multi-disciplinary open access archive for the deposit and dissemination of scientific research documents, whether they are published or not. The documents may come from teaching and research institutions in France or abroad, or from public or private research centers.
L'archive ouverte pluridisciplinaire HAL, est destinée au dépôt et à la diffusion de documents scientifiques de niveau recherche, publiés ou non, émanant des établissements d'enseignement et de recherche français ou étrangers, des laboratoires publics ou privés. 


\title{
Partitioning of Heavy Metals in Municipal Solid Waste Pyrolysis, Gasification, and Incineration
}

\author{
Jun Dong, ${ }^{\dagger \dagger}$ Yong Chi, ${ }^{*}{ }^{\dagger}$ Yuanjun Tang, ${ }^{\dagger}$ Mingiiang Ni, $^{\dagger}$ Ange Nzihou, ${ }^{\ddagger}$ Elsa Weiss-Hortala, \\ and Qunxing Huang ${ }^{\dagger}$ \\ ${ }^{\dagger}$ State Key Laboratory of Clean Energy Utilization, Zhejiang University, Hangzhou, Zhejiang 310027, China \\ ${ }^{\ddagger}$ Mines Albi, UMR CNRS 5302, Centre RAPSODEE, Université de Toulouse, Campus Jarlard, Albi Cedex 09, France
}

\begin{abstract}
Heavy metal emission is a great environmental concern for the development of municipal solid waste (MSW) thermal treatment techniques. In this study, both experimental investigations and theoretical simulations are carried out to identify the partitioning of heavy metals between the gaseous phase and solid fractions during pyrolysis, gasification, and incineration of simulated MSW. Two types of incinerators are used. A tubular furnace is applied to evaluate the evaporation of metals from residues, whereas the metal distribution among bottom ash, cyclone fly ash, and filter fly ash is further examined in a fluidized bed. Six target metals $(\mathrm{Cd}, \mathrm{Pb}, \mathrm{Zn}, \mathrm{Cu}, \mathrm{Cr}$, and $\mathrm{Ni}$ ) are studied. Results show that a reductive atmosphere favors the evaporation of $\mathrm{Cd}$ and $\mathrm{Zn}$ but refrains $\mathrm{Cu}, \mathrm{Ni}$, and $\mathrm{Cr}$ volatilization, because metals are mainly reduced to their elemental form or sulfide, according to thermodynamic equilibrium calculation. Oxides are the dominant species under oxidizing condition due to the abundance of alkalis. $\mathrm{Pb}$ behaved differently, most probably by forming stable metal-matrix compounds such as $\mathrm{Pb}_{3} \mathrm{Ca}_{2} \mathrm{Si}_{3} \mathrm{O}_{11}$ and $\mathrm{PbZnSiO}_{4}$. The cyclone ash is then separated into different sizes. The metal concentrations recorded reveal that most of the vaporized metals are transferred to the cyclone at its working temperature of $350-600{ }^{\circ} \mathrm{C}$ by an evaporation and condensation process; however, entrainment is also a determining factor for the transfer of less-volatile metals. Overall, parameters determining the transfer of heavy metals during MSW thermal treatment can be summarized as (i) metal speciation affected by redox atmosphere, temperature, and the presence of alkalis, chloride, sulfur, and other mineral substances; (ii) system characteristics, such as furnace type and cyclone temperature; and (iii) mechanical entrainment of particles caused by gas velocity.
\end{abstract}

\section{INTRODUCTION}

Guided by the waste management hierarchy, ${ }^{1}$ municipal solid waste (MSW) incineration has played a gradually more important role over the past few decades. Compared to landfill, incineration benefits from considerable waste volume reduction, completely organic destruction, and the added ability to reclaim a significant amount of energy. ${ }^{2}$ In China, a total of 166 MSW incineration plants with treatment capacity of 492300 tons $\cdot$ day $^{-1}$ were in operation by the end of 2013 , accounting for $30 \%$ of the total MSW treated. ${ }^{3}$ The proportion of incineration is expected to achieve $35 \%$ in 2015 according to the National Twelfth Five-year Plan. ${ }^{4}$ In spite of the advantages derived from incineration, toxic emission of dioxin remains a thorny issue, and the energy efficiency is relatively low, e.g., 16-24\%. In recent years, advanced MSW thermal technologies, pyrolysis and gasification, have received increasing attention. It is proven that, in an oxygen-deficient atmosphere, the formation of dioxin and $\mathrm{NO}_{x}$ can both be diminished significantly. ${ }^{5}$ Moreover, the generated synthesis gas can be utilized in different technical approaches, offering a potential of higher energy efficiency. Therefore, MSW pyrolysis and gasification are regarded as viable alternatives for traditional incineration even though few plants really operate. ${ }^{6}$

However, metal species contained in MSW will not be destroyed during high-temperature conversion but will instead be concentrated in the solid residues or escape as airborne aerosols exiting the stack. Heavy metal is one of the most toxic contaminants that can accumulate in the human body such as kidneys, bones, and liver, causing serious health disorders. ${ }^{7,8}$
Certain metals such as $\mathrm{Cu}$ are proven to act as catalysts for dioxin formation. ${ }^{9}$ Heavy metal emissions thus become a great environmental concern. ${ }^{10,11}$ Previous studies have revealed that the partitioning of heavy metals is affected by various factors such as (i) feedstock characteristics, i.e., physical and chemical properties of the heavy metals, the content of chlorine, sulfur, and alkalis; (ii) operating conditions, such as temperature, redox environment, residence time, incinerator type, and so on; and (iii) entrapment techniques, including flue gas treatment facilities, catalysts, and sorbents. ${ }^{12-15}$ Because the oxidation/ reduction atmosphere and the operation parameters are quite different during MSW pyrolysis, gasification, and incineration, it is necessary to understand the transfer of heavy metals in these three generic groups of processes.

To date, numerous studies have discussed the fate of heavy metals during MSW incineration. ${ }^{12,16-19}$ Nevertheless, the effect of MSW pyrolysis and gasification processes on the migration of heavy metals has not been investigated clearly. Yu et al. investigated the vaporization of metals for different oxygen concentrations $(0 \%, 5 \%$, and $20 \%),{ }^{20}$ showing that the evaporation of $\mathrm{Cd}, \mathrm{Pb}, \mathrm{Cu}$, and $\mathrm{Zn}$ was enhanced with decreasing oxygen content. However, $\mathrm{Wu}$ et al. drew an opposite conclusion. ${ }^{21}$ They mentioned that gasification could lower the evaporation of metals; $\mathrm{Cd}, \mathrm{Pb}$, and $\mathrm{Cr}$ concentration in the fly ash after gasification was about $3.3-10 \%$ of that after 
incineration. Jakob et al. analyzed the thermal treatment of MSW fly ash, ${ }^{22}$ observing that a reductive atmosphere was effective for $\mathrm{Zn}$ evaporation but restrained $\mathrm{Cu}$ volatilization. On the other hand, to clarify the effect of redox atmosphere, previous studies are mostly based on theoretical calculation. $^{23-25}$ Studies that incorporate both theoretical and experimental investigations are quite lacking, especially taking into account the complex composition of the reaction systems and feedstock characteristics. To better reveal the tendency toward metal volatilization and the accompanying reaction mechanisms during MSW thermal treatment, such a quantitative study is in urgent demand.

Accordingly, the objective of the present work is to determine the effect of redox atmosphere on the partitioning of heavy metals during MSW thermal treatment. Six target heavy metals, including $\mathrm{Cd}, \mathrm{Zn}, \mathrm{Pb}, \mathrm{Cu}, \mathrm{Ni}$, and $\mathrm{Cr}$, are investigated in a temperature range of $550-850{ }^{\circ} \mathrm{C}$. MSW pyrolysis, gasification, and incineration tests are performed in both a tubular furnace and a fluidized-bed reactor, which serve as models of the two most representative types of incinerator. Besides, thermodynamic equilibrium is also calculated, using the same reaction conditions as those applied in the experiments. The knowledge gained would assist in understanding the metal speciation and transfer mechanism during MSW thermal treatment and provide scientific experience to develop effective heavy metal control strategies.

\section{MATERIALS AND METHODS}

2.1. Sample Preparation. The handling of actual MSW in laboratory scale is difficult due to the heterogeneity of the feedstock and the uncontrollability in measurement. ${ }^{26}$ Thus, simulated MSW (SMSW) is used in each test. The S-MSW is prepared based on the typical MSW physical composition in China, ${ }^{27}$ consisting of food waste, paper, plastic, textile, timber, and rubber. The inert portion is added separately, either as $\mathrm{SiO}_{2}$ powder in the tubular furnace or as bed material (silica sand) in the fluidized bed. The composition, elementary analysis, and heating value of the S-MSW are shown in Table 1.

Table 1. Composition and Characteristics of the Simulated Municipal Solid Waste

\begin{tabular}{llll}
\multicolumn{2}{c}{ composition (as received basis) } & \multicolumn{2}{c}{ elementary analysis (air-dried basis) } \\
rice & $29 \%$ & $\mathrm{C}$ & $48.4 \%$ \\
cabbage & $29 \%$ & $\mathrm{H}$ & $6.3 \%$ \\
cardboard & $13 \%$ & $\mathrm{O}$ & $29.2 \%$ \\
polyethylene (PE) & $17 \%$ & $\mathrm{~N}$ & $0.8 \%$ \\
polyvinyl chloride (PVC) & $3 \%$ & $\mathrm{~S}$ & $0.3 \%$ \\
sawdust & $5 \%$ & $\mathrm{Cl}$ & $1.6 \%$ \\
cotton fabric & $2 \%$ & moisture & $9.2 \%$ \\
scrap tire & $2 \%$ & ash & $4.2 \%$ \\
& & heating value & $22.5 \mathrm{MJ} \cdot \mathrm{kg}^{-1}$ \\
\hline
\end{tabular}

The S-MSW is crushed and sieved to $\sim 2 \mathrm{~mm}$. Because the background level of heavy metals in the S-MSW is negligible, target metals are added using impregnation method. ${ }^{20}$ Weighted metal chlorides are dissolved in distilled water. The S-MSW is immersed and stirred in this solution for $12 \mathrm{~h}$ to achieve good mixing and then dried at $85{ }^{\circ} \mathrm{C}$ for $24 \mathrm{~h}$. The metal concentration $\left(\mathrm{mg} \cdot \mathrm{kg}^{-1}\right)$ of the acquired feedstock is $575.7(\mathrm{Cd}), 3926(\mathrm{Zn}), 864.8(\mathrm{~Pb}), 2301(\mathrm{Cu}), 931.8$ $(\mathrm{Ni})$, and $615.1(\mathrm{Cr})$, respectively.

2.2. Tubular Furnace Experiments. A horizontal tubular furnace is used to investigate the volatilization of heavy metals. The experimental system comprises an electrically heated tubular furnace, a gas source and flow controller, and a flue gas absorption train (Figure
1). The tube is $40 \mathrm{~mm}$ in inner diameter and $700 \mathrm{~mm}$ in length, with a thermocouple inserted at the center monitoring the furnace temper-

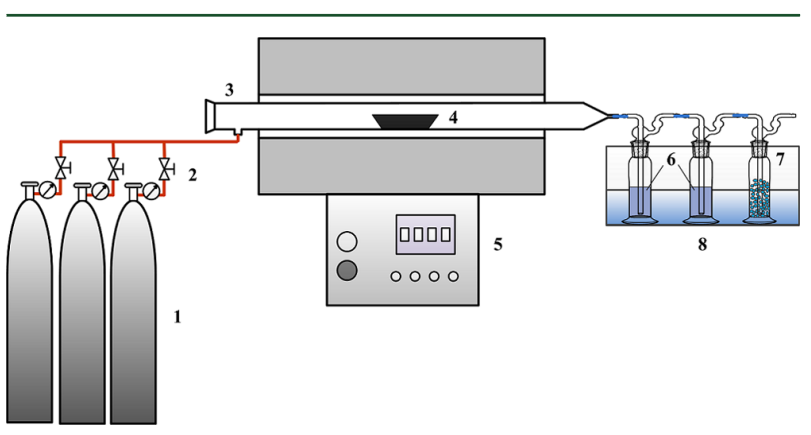

Figure 1. Schematic diagram of the horizontal tubular furnace: 1 , gas source; 2, gas flow controller; 3 , horizontal quartz tubular furnace; 4, quartz boat; 5, electric heater and temperature controller; 6, absorption solution with $5 \% \mathrm{HNO}_{3}+10 \% \mathrm{H}_{2} \mathrm{O}_{2} ; 7$, silica gel; 8, ice-water bath.

ature. The flue gas passes successively through three impingers immersed in an ice-water bath to capture heavy metals. The first and second impringers contain $5 \% \mathrm{HNO}_{3}$ and $10 \% \mathrm{H}_{2} \mathrm{O}_{2}$ as absorption solution, and the third one is filled with silica gel for moisture removal. ${ }^{28}$

Reductive and oxidative conditions are supplied by $\mathrm{N}_{2}$, model synthetic gas, and air, respectively. The model gas is composed of $1.0 \%$ $\mathrm{H}_{2}, 1.5 \% \mathrm{CH}_{4}, 3.0 \% \mathrm{CO}, 6.5 \% \mathrm{CO}_{2}$, and $88.0 \% \mathrm{~N}_{2}$, a composition typical for MSW air gasification. ${ }^{29}$

A total of 12 tests are conducted, with their detailed working conditions listed in Table 2. For each test, $3 \mathrm{~g}$ of S-MSW together with

Table 2. Working Conditions Used for Tubular Furnace Experiment

\begin{tabular}{lccc} 
atmosphere & gas flow rate $\left(1 \cdot \mathrm{min}^{-1}\right)$ & temperature $\left({ }^{\circ} \mathrm{C}\right)$ & $\begin{array}{c}\text { reaction time } \\
(\mathrm{min})\end{array}$ \\
$\mathrm{N}_{2}$ & 1.5 & $550,650,750$, & 30 \\
$\begin{array}{l}\text { synthetic } \\
\text { gas }\end{array}$ & & 850 & 30 \\
air & & & 15 \\
\hline
\end{tabular}

$0.5 \mathrm{~g}$ of $\mathrm{SiO}_{2}$ is mixed and placed in a dried quartz boat. The gas is introduced into the tube at the heating stage of the experiment. When the furnace is heated to the desired temperature, the boat is pushed to the center of the combustion chamber. The combustion time is determined beforehand to ensure complete reaction. At the end of the experiment, the heating source and air supply are turned off. The boat is pulled out of the tube carefully after the furnace has cooled down to room temperature. The heavy metal contents in both solid residues and gaseous phase are detected. Connection pipes and the tube furnace are flushed by absorption solution, and then this solution is mixed with the gas sample.

2.3. Fluidized-Bed Experiments. A schematic diagram of the fluidized-bed experimental apparatus is depicted in Figure 2. The furnace is $60 \mathrm{~mm}$ in inner diameter and $1100 \mathrm{~mm}$ in height. It is electrically heated by three stages of resistance wire. Three K-type thermocouples are installed to monitor the reaction temperature at the top, middle, and bottom of the furnace. A speed-adjustable screw feeder is feeding the S-MSW into the furnace continuously. The fluidizing gases are air and $\mathrm{N}_{2}$; the fluidizing flow rate is kept the same $\left(U_{\mathrm{m}}=0.183 \mathrm{~N} \cdot \mathrm{m} \cdot \mathrm{s}^{-1}=1.5 U_{\mathrm{mf}}\right)$. The flue gas is treated by a cyclone separator, a glass-fiber filter, and the impinger train. The filter is maintained at $200{ }^{\circ} \mathrm{C}$ using heating tape to prevent vapor condensing in the pipe. Heavy metals in the flue gas are sampled by the same aforementioned method. 


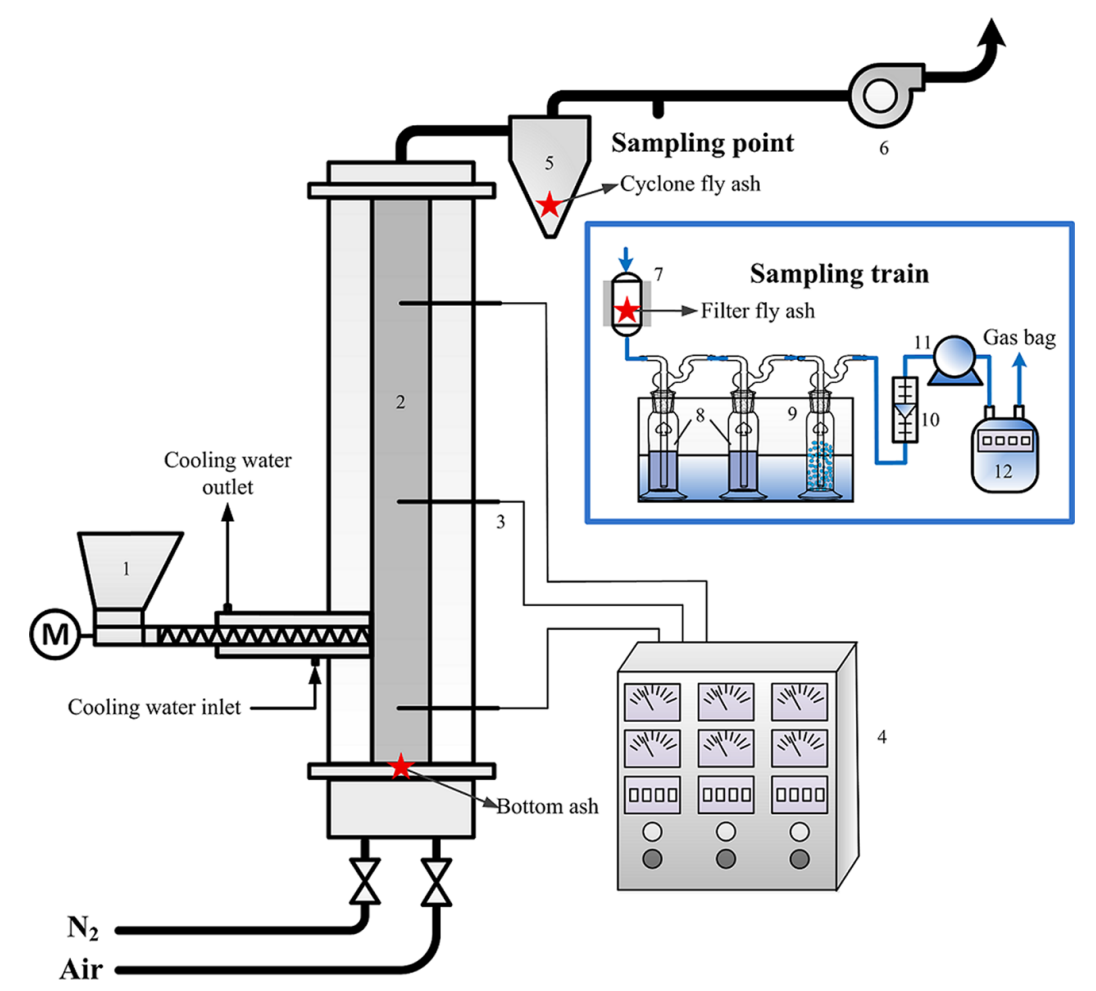

Figure 2. Schematic diagram of the fluidized-bed furnace: 1, screw feeder; 2, furnace; 3, thermocouples; 4, controller; 5, cyclone separator; 6 , induced draft fan; 7, glass-fiber filter covered with a heating tape; 8, absorption solution with $5 \% \mathrm{HNO}_{3}+10 \% \mathrm{H}_{2} \mathrm{O}_{2} ; 9$, silica gel; 10 , rotor flowmeter; 11, vacuum pump; 12, accumulative flowmeter.
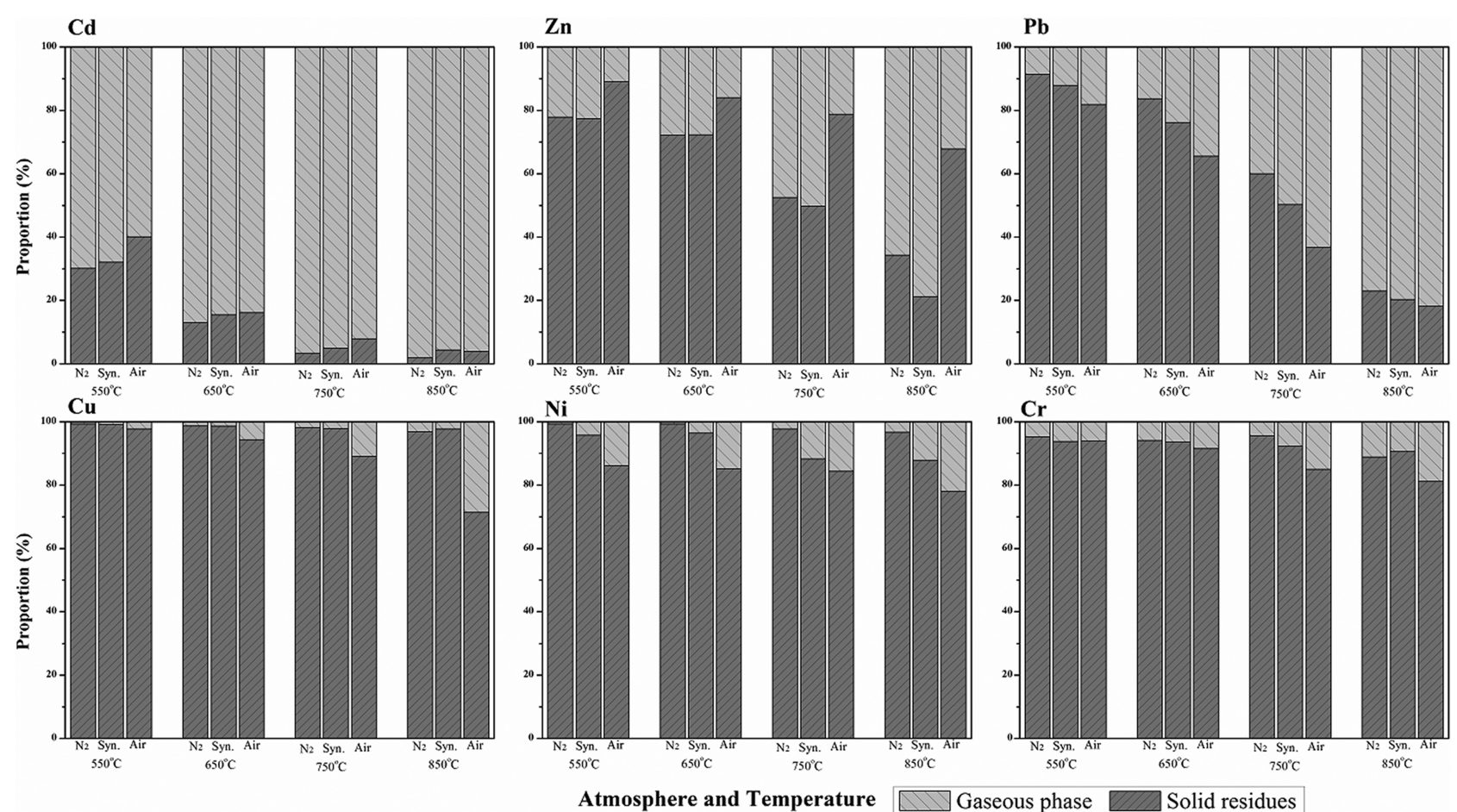

Figure 3. Evaporation S-MSW of heavy metals from tubular furnace experiment. "Syn." is short for synthetic gas.

For each test, the S-MSW feeding rate is varied to satisfy pyrolysis, gasification, and incineration conditions. The equivalence ratios for gasification and incineration are set at 0.4 and 1.2 , respectively. Bed material, with particle size of $0.28-0.45 \mathrm{~mm}$, is put into the furnace before heating. When the desired temperature is reached, the S-MSW begins to be fed into the furnace. Flue gas $(100 \mathrm{~L})$ is taken 

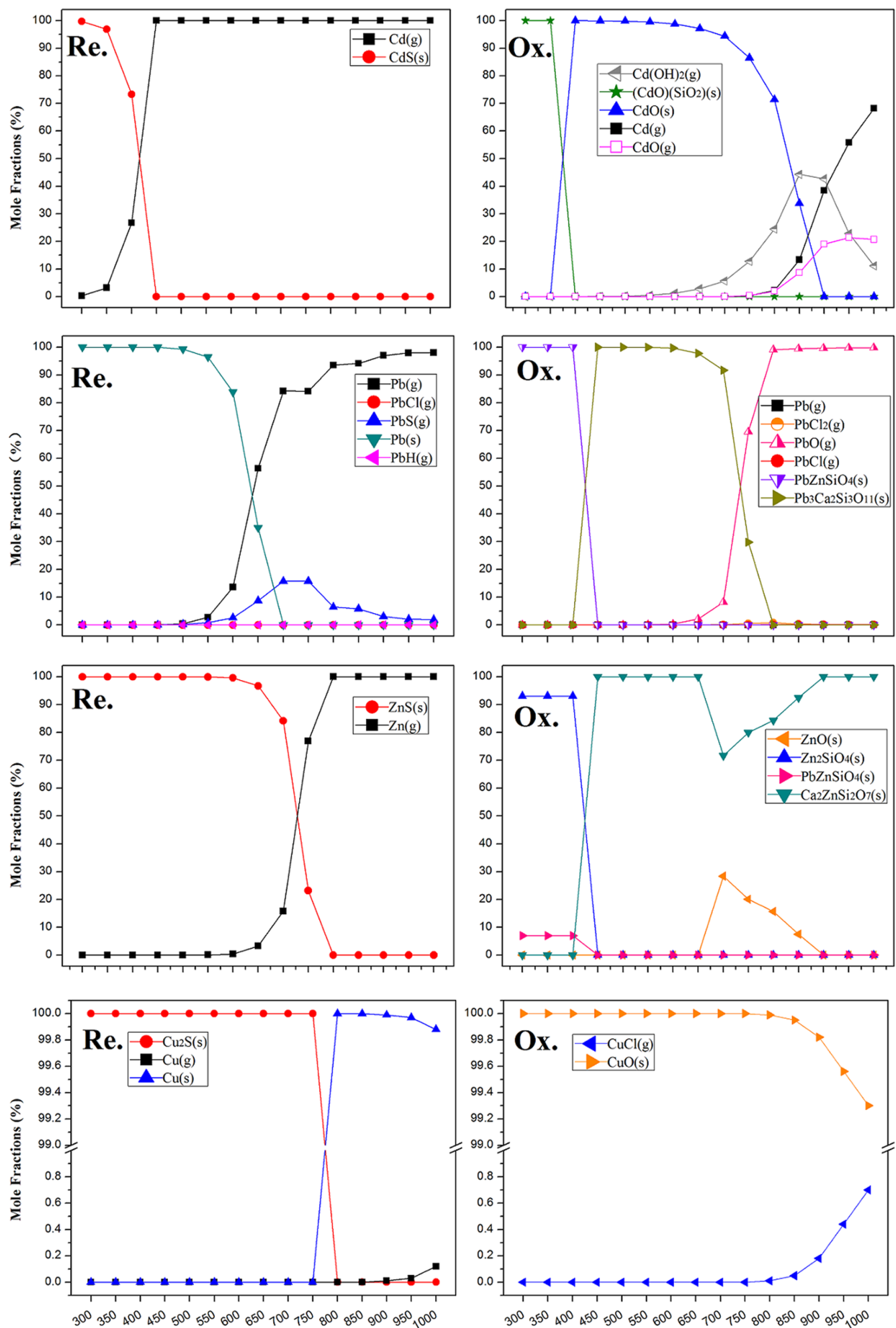

Temperature $\left({ }^{\circ} \mathrm{C}\right)$

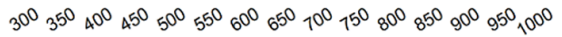

Temperature $\left({ }^{\circ} \mathrm{C}\right)$

Figure 4. Thermodynamic equilibrium distribution of heavy metals under different redox atmosphere. "Re." represents reductiveand the results under $\mathrm{N}_{2}$ atmosphere are presented; "Ox." is short for oxidative atmosphere.

isokinetically once the system achieves stability. Gas bags are used to collect the dry and incondensable gas; the total generated gas is calculated based on $\mathrm{N}_{2}$ balance. Heavy metals in the bottom ash, cyclone fly ash, and filter fly ash are all detected.
2.4. Thermodynamic Simulation. Thermodynamic simulation software, FactSage, is used to predict the equilibrium metal volatilization tendencies under different thermal conditions. The program uses the principle of minimizing the total Gibbs free energy of 
the system to calculate the thermodynamic equilibrium. The final equilibrium state is obtained by determining all possible species that are derived from the input elements. The modeling could provide a better understanding of the experimental results. When both experimental and simulative data are assimilated, the major metal species and possible reaction mechanisms during the specific thermal process can be proposed.

The calculation conditions are set similar to those applied in the experiments. The S-MSW used in the simulation is assumed to consist of the basic elements $\mathrm{C}, \mathrm{H}, \mathrm{O}, \mathrm{N}, \mathrm{S}, \mathrm{Cl}$, and $\mathrm{H}_{2} \mathrm{O}$. The six heavy metals are input as metal chlorides. Besides, both alkali metals $(\mathrm{K}, \mathrm{Ca}, \mathrm{Na}$, and $\mathrm{Mg})$ and inert $\left(\mathrm{SiO}_{2}\right)$ are considered, since they have proven to be important in the vapor of heavy metals. ${ }^{23,30}$ Products output includes gas, pure solids, and pure liquids. The air supply strategies are set the same as that in the tubular furnace to represent reductive and oxidative conditions. The air is assumed to be composed of $79 \% \mathrm{~N}_{2}$ and $21 \%$ $\mathrm{O}_{2}$. Equilibrium calculations are performed in the temperature range of $300-1000{ }^{\circ} \mathrm{C}$, and the total pressure is 1 atm.

2.5. Analysis Method. To ensure the reliability of test data, each experiment is repeated three times and the average value is adopted. The gas composition resulting from fluidized-bed tests is determined by gas chromatography (micro GC-490 analyzer, Agilent). To analyze heavy metal concentrations, solid samples as the S-MSW, bottom ash, cyclone fly ash, and filter fly ash are digested with a mixture of $\mathrm{HNO}_{3}$, $\mathrm{HCl}$, and $\mathrm{HF}$ in a microwave oven. The digested samples together with gas samples are then analyzed by inductively coupled plasma mass spectrometry (Xeries II; Thermo Fisher Scientific, Inc., U.S.A.).

\section{RESULTS AND DISCUSSION}

\subsection{Evaporation of Heavy Metals in Tubular Furnace.}

Under the test conditions in the tubular furnace, the mass balance closure of heavy metals is in a range of $84-97 \%$, which is quite acceptable. ${ }^{31}$ Heavy metals evaporation under different redox atmospheres and temperatures is depicted in Figure 3.

Generally, the proportion of heavy metals in the gaseous phase is increased gradually with temperature, because a higher temperature could raise the vapor pressure of metal compounds and enhance the rates of diffusion. ${ }^{10,32}$ The redox atmosphere poses great influences on the evaporation of heavy metals: $\mathrm{Cd}$ and $\mathrm{Zn}$ are found to be more volatile under reductive atmosphere, whereas an oxidative atmosphere effectively promotes the volatilization of $\mathrm{Pb}, \mathrm{Cu}, \mathrm{Ni}$, and $\mathrm{Cr}$. When $\mathrm{N}_{2}$ is injected instead of air, the evaporation of $\mathrm{Cd}$ and $\mathrm{Zn}$ is increased by $2-10 \%$ and $11-34 \%$ under experimental temperature ranges, respectively. On the contrary, $\mathrm{Pb}$ has a higher tendency to evaporate in oxidative conditions, increasing by $5-23 \%$ compared to $\mathrm{N}_{2}$ atmosphere. As least volatile metals, $29 \% \mathrm{Cu}, 22 \% \mathrm{Ni}$, and $19 \% \mathrm{Cr}$ are released in an oxidative atmosphere at $850^{\circ} \mathrm{C}$, which are $\sim 2-9$ times higher than those in $\mathrm{N}_{2}$.

To better understand the effect of redox atmosphere on the volatility of metals, a thermodynamic equilibrium calculation is carried out, with some of the most typical results presented in Figure 4. It is shown that metals are alternatively present as elemental form or sulfide under reducing conditions. At lower temperatures, sulfides are the dominant species and metals are mainly retained in the solid phase. The mass of elemental metals increases with elevated temperature. $\mathrm{Cd}, \mathrm{Pb}$, and $\mathrm{Zn}$ vaporize and thus are found in the flue gas; nevertheless, the majority of metallic $\mathrm{Cu}, \mathrm{Ni}$, and $\mathrm{Cr}$ remain in the solid residues due to their relatively high boiling point. In the case of oxidizing conditions, oxides are the dominant metal species. Part of $\mathrm{Pb}$ and $\mathrm{Cu}$ is found as gaseous $\mathrm{PbCl}, \mathrm{PbCl}_{2}$, and $\mathrm{CuCl}$ when the temperature is $>6500^{\circ} \mathrm{C}$. The retention of $\mathrm{Zn}$ in the solid phase remains strong at higher temperatures due to the formation of complex zinc-matrix compound $\left(\mathrm{Ca}_{2} \mathrm{ZnSi}_{2} \mathrm{O}_{7}\right)$. The thermodynamic simulation results are in good accordance with the experimental observations. The significant difference in metal volatility characteristics under redox atmosphere can be explained by the formation of different chemical species. The evaporation of $\mathrm{Cd}$ and $\mathrm{Zn}$ is retrained under oxidative atmosphere, because the boiling points of $\mathrm{CdO}, \mathrm{ZnO}$, or zinc-matrix compounds are higher than those of their metallic forms. On the other hand, $\mathrm{PbO}$ is volatile to promote the evaporation of $\mathrm{Pb}$ under oxidative atmosphere. The boiling points of elemental $\mathrm{Cu}, \mathrm{Ni}$, and $\mathrm{Cr}$ are significantly higher than their oxides or chlorides, so that these metals can hardly be released under reducing conditions.

Besides, theoretical calculations also indicate that certain metal-matrix compounds such as $(\mathrm{CdO})\left(\mathrm{SiO}_{2}\right), \mathrm{Pb}_{3} \mathrm{Ca}_{2} \mathrm{Si}_{3} \mathrm{O}_{11}$, $\mathrm{Zn}_{2} \mathrm{SiO}_{4}$, etc. are formed under oxidative atmosphere; however, these products are not found under reducing conditions. The results could also partly account for the low volatilization of $\mathrm{Cd}$ and $\mathrm{Zn}$ during S-MSW incineration experiments. Especially, Zn evaporation shows a strongly declining tendency under oxidative atmosphere. Consulting the vapor pressure of $\mathrm{Zn}$ compounds, it is expected that the volatility of $\mathrm{Zn}$ should be in a same level as $\mathrm{Cd}$. The observed phenomena may be caused by the incorporation reaction of metals with $\mathrm{SiO}_{2}$, which will be enhanced with increasing oxygen concentration (eq 1)..$^{13,15,33}$ Under the incineration process, the formation of binary or ternary metal oxides is favored. These nonvolatile compounds can fill the pores and inhibit the volatilization of non-reacted metals, resulting in less metal evaporation. ${ }^{20,34}$

$$
\mathrm{MCl}_{2}+\mathrm{SiO}_{2}+\mathrm{O}_{2} \rightarrow \mathrm{MO}_{2} \cdot \mathrm{SiO}_{2}+\mathrm{Cl}_{2}
$$

It is well-recognized that the presence of chlorine would have a positive effect on the evaporation of heavy metals by forming volatile metal chlorides. ${ }^{20,22}$ Although $\sim 1.6 \%$ of $\mathrm{Cl}$ is contained in the S-MSW and metal chlorides are added as metal source, the evaporation of metals is not as much as expected, i.e., $>70 \%$ of $\mathrm{Cu}, \mathrm{Ni}$, and $\mathrm{Cr}$ are retrained in the solid residues under oxidative atmosphere. This fact is verified by theoretical simulation that oxides are the major compounds under oxidizing condition. Figure 5 exhibits the equilibrium distribution of chlorine compounds under oxidizing condition. It is found that the total amounts of alkali chlorides produced are several orders of magnitude higher than heavy metal chlorides. Previous studies have proposed the preferential reaction of $\mathrm{Cl}$ with alkali metals. ${ }^{31,35}$ Correlating with our experiments, the alkali metals are in strong abundance in the SMSW ( $\mathrm{Cl} /$ alkali metals is $\sim 0.08)$; therefore, the suppression of the $\mathrm{Cl}$ effect on heavy metal volatility can be expected.

3.2. Partitioning of Heavy Metals in Fluidized-Bed Furnace. Figure 6 shows the effects of equivalence ratio and temperature on the phase transfer of metals from fluidized-bed experiments. Results are presented as a mass percentage of the input metals to reflect the recovery rate. The total concentrations of metals cannot make $100 \%$; possibilities for this incomplete closure will be discussed later in section 3.3. Metal partitioning is split over bottom ash, cyclone fly ash, and filter fly ash, while essentially no metals are detected in the flue gas. With respect to the relative distribution of metals over different ash fractions, more volatile metals such as $\mathrm{Cd}$ and $\mathrm{Pb}$ are enriched in filter ash to a large extent. The majority of $\mathrm{Cu}$, $\mathrm{Ni}$, and $\mathrm{Cr}$ are retained in bottom ash or cyclone ash.

Consulting the distribution of metals in the bottom ash, the obtained results exhibit a quite similar changed tendency with 


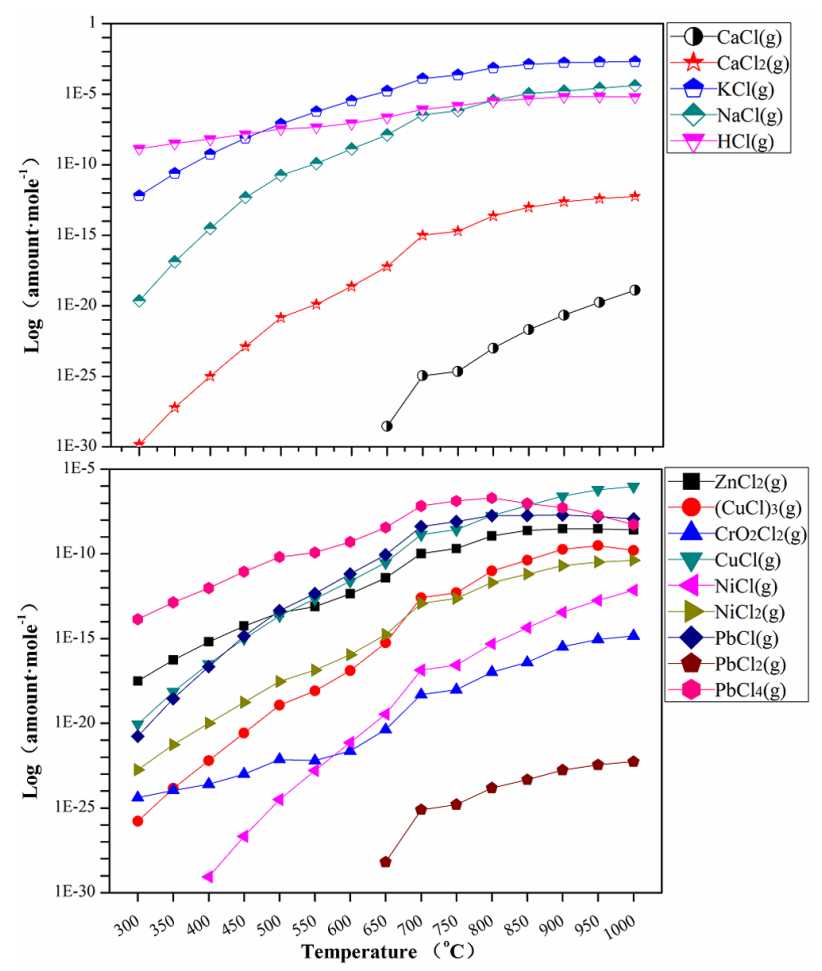

Figure 5. Thermodynamic equilibrium distribution of chlorine compounds under oxidizing condition.

tubular furnace tests. Reductive atmosphere has a positive effect on the evaporation of $\mathrm{Cd}, \mathrm{Zn}$, and $\mathrm{Pb}$. In contrast, $\mathrm{Cu}, \mathrm{Ni}$, and $\mathrm{Cr}$ in the bottom ash under reductive atmosphere are $\sim 1-7$ times of those under oxidative atmosphere. However, the observed $\mathrm{Pb}$ vaporization is opposite compared to that in tubular furnace. It is found that, under fluidized-bed condition, $\mathrm{Pb}$ becomes less volatile during the incineration process. By checking the equilibrium prediction in Figure 4, it is speculated that the incorporation reaction (eq 1) may be favored. Because the fluidized bed affords more intense mixing and contact between feedstock and bed materials, ${ }^{36}$ the formation of matrix species such as $\mathrm{Pb}_{3} \mathrm{Ca}_{2} \mathrm{Si}_{3} \mathrm{O}_{11}$ and $\mathrm{PbZnSiO}_{4}$ may be enhanced and postpone or reduce the evaporation of $\mathrm{Pb}$ compounds. ${ }^{20,37,38}$ Liu et al. investigated the sewage sludge incineration ash by X-ray diffraction (XRD) analysis and found that $\mathrm{Pb}$ was primarily formed as $\mathrm{PbSiO}_{4}$ in the bottom ash, which is nonvolatile. ${ }^{39}$ Zhang et al. conducted a 2 -year field study on two large-scale incinerators, ${ }^{12}$ observing that only $21-$ $54 \%$ of $\mathrm{Pb}$ was transferred to the gaseous phase despite its high volatility. On the other hand, $\mathrm{Zn}$ also exhibits abilities to react with other metals to form complex compounds. ${ }^{23,34}$ It is thus suggested that the metal-matrix reaction is one of the most important aspects affecting the transfer of metals and is correlated to the presence of mineral substances, alkalis, and the interactions among different existing metals.

As least-volatile metals, lower volatility is found for $\mathrm{Cu}, \mathrm{Ni}$, and $\mathrm{Cr}$ in a reductive than in an oxidative environment. The result is in good agreement with the tubular furnace tests, which confirms that metals are mainly reduced to elemental form or sulfide under reducing atmosphere. The proportion of $\mathrm{Cu}, \mathrm{Ni}$, and $\mathrm{Cr}$ in the cyclone ash is increasing with elevated equivalence ratio. However, no obvious trend is found for their transfer to the filter. The proportion of $\mathrm{Cu}, \mathrm{Ni}$, and $\mathrm{Cr}$ in the filter ash is found similar (1-9\%) and fluctuates with equivalence ratio and temperature. It can be postulated that the condensation of $\mathrm{Cu}, \mathrm{Ni}$, and $\mathrm{Cr}$ occurs most probably in the
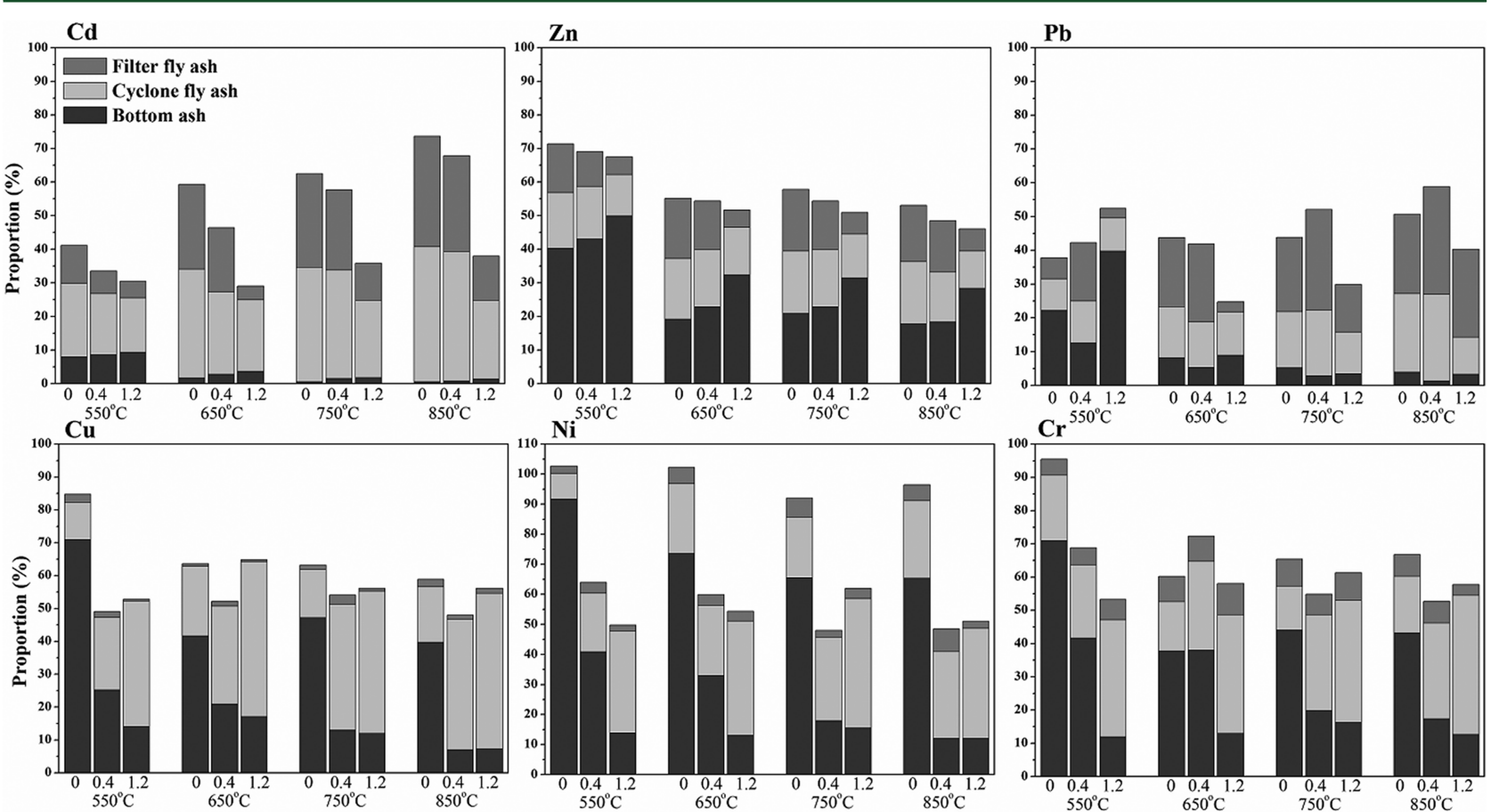

Equivalence ratio and Temperature

Figure 6. Partitioning S-MSW of heavy metals from fluidized-bed furnace experiment. Equivalence ratio 0, 0.4, and 1.2 represents pyrolysis, gasification, and incineration, respectively. 

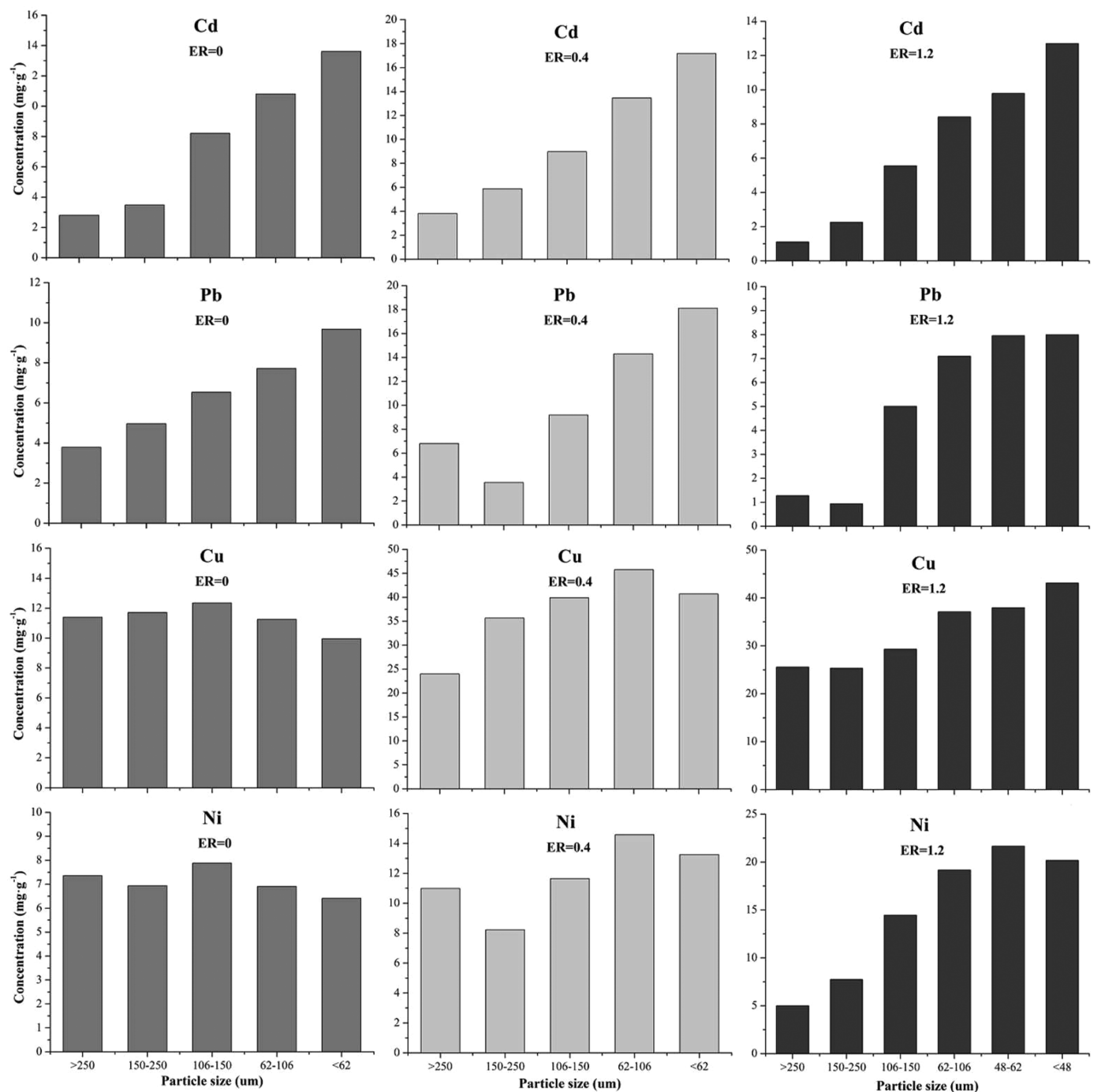

Figure 7. Concentration of heavy metals in the cyclone ash with different particle sizes. Tests at $850{ }^{\circ} \mathrm{C} . \mathrm{ER}=0,0.4$, and 1.2 represents pyrolysis, gasification, and incineration, respectively.

Table 3. Concentration of Heavy Metals in Different Ash Fractions; Tests at $850{ }^{\circ} \mathrm{C}\left(\mathrm{mg}^{\circ} \mathrm{g}^{-1}\right.$; dry weight basis)

\begin{tabular}{|c|c|c|c|c|c|c|c|}
\hline & & $\mathrm{Cd}$ & $\mathrm{Zn}$ & $\mathrm{Pb}$ & $\mathrm{Cu}$ & $\mathrm{Ni}$ & $\mathrm{Cr}$ \\
\hline \multirow[t]{3}{*}{ bottom ash } & $\mathrm{ER}=0^{a}$ & 0.03 & 7.44 & 0.36 & 9.75 & 6.49 & 2.84 \\
\hline & $\mathrm{ER}=0.4$ & 0.11 & 17.65 & 0.27 & 4.00 & 2.75 & 2.61 \\
\hline & $\mathrm{ER}=1.2$ & 0.22 & 29.87 & 0.77 & 4.50 & 3.02 & 2.09 \\
\hline \multirow[t]{3}{*}{ cyclone fly ash } & $\mathrm{ER}=0$ & 7.05 & 22.10 & 6.13 & 11.77 & 7.32 & 3.18 \\
\hline & $\mathrm{ER}=0.4$ & 9.65 & 25.41 & 9.65 & 39.73 & 11.74 & 7.72 \\
\hline & $\mathrm{ER}=1.2$ & 4.44 & 14.45 & 3.11 & 29.22 & 11.23 & 6.91 \\
\hline \multirow[t]{3}{*}{ Filter fly ash } & $\mathrm{ER}=0$ & 7.01 & 14.25 & 7.51 & 1.01 & 0.59 & 0.79 \\
\hline & $\mathrm{ER}=0.4$ & 4.14 & 9.21 & 6.95 & 0.42 & 1.72 & 0.56 \\
\hline & $\mathrm{ER}=1.2$ & 0.73 & 1.65 & 2.15 & 0.33 & 0.20 & 0.17 \\
\hline
\end{tabular}

${ }^{a} \mathrm{ER}=$ equivalence ratio; $\mathrm{ER}=0,0.4$, and 1.2 represents pyrolysis, gasification, and incineration, respectively.

cyclone; their transfer to the filter ash is primarily due to entrainment. Meanwhile, results also reveal that $\sim 13-84 \%, 8-$ $72 \%$, and $21-72 \%$ of the detected $\mathrm{Cu}, \mathrm{Ni}$, and $\mathrm{Cr}$, respectively, is transferred to the cyclone ash. The values are much higher than those from tubular furnace tests and literature. ${ }^{12,40,41}$ The high gas velocity used in the fluidized bed is responsible for this distinction, which has also influence on the transfer of heavy metals by entrainment.

To verify the metal migration mechanism, the cyclone ash samples are then separated into different particle sizes by vibration sieve (>250, 150-250, 106-150, 62-106, 48-62, and $<48 \mu \mathrm{m}$ ). The metal concentration of the fractioned ashes is detected and illustrated in Figure 7. Results demonstrate that 
the concentration of $\mathrm{Cd}$ increases with decreasing particle sizes no matter whether under reductive or oxidative atmosphere, indicating that the transfer of $\mathrm{Cd}$ to the cyclone is mainly from evaporation. Similar distribution behavior of $\mathrm{Pb}$ is observed. However, $\mathrm{Cu}$ and $\mathrm{Ni}$ are distributed uniformly with different sizes under pyrolysis and gasification cases. It reveals that although part of $\mathrm{Cu}$ and $\mathrm{Ni}$ is found in the cyclone ash under reductive condition, they are dominantly transferred by entrainment. On the contrary, these less-volatile metals exhibit enrichment in finer particles under incineration process, proving that not only entrainment but also evaporation determines their migration.

Table 3 presents the concentration of metals in different ash fractions. Most heavy metals are enriched in the cyclone. This confirms that most of the vaporized metals are condensed upon cooling at the working temperature of the cyclone, i.e., 350$600{ }^{\circ} \mathrm{C}$. Besides, entrainment also contributes to the high metal concentrations in the cyclone, which is especially outstanding for less-volatile metals based on the analysis in Figure 7. The concentration of $\mathrm{Cd}$ and $\mathrm{Pb}$ is relatively high in the filter ash under reductive atmosphere, which is comparable to or even exceeds that content in the cyclone ash. More volatile $\mathrm{Cd}$ and $\mathrm{Pb}$ species easily form under reductive atmosphere and will remain in the gaseous phase after passing through the cyclone. Therefore, for both pyrolysis and gasification processes, effective cleaning prior to syngas utilization should be concerned. Meanwhile, a particular enrichment of $\mathrm{Zn}$ in the bottom ash is observed under oxidative atmosphere. Special attention should be paid to this, because the metal concentration may exceed the limited value if the incineration bottom ash is further recycled and reutilized.

3.3. Discussion. The average recovery rate of heavy metals under fluidized-bed tests is $<50 \%$, which is significantly lower than that from the tubular furnace. Several possibilities may account for this. Some metals may be condensed, depositing on the furnace wall, cyclone, and piping. Lower recoveries of 25$74 \%$ are found for $\mathrm{Cd}, \mathrm{Zn}$, and $\mathrm{Pb}$; on the contrary with $48-$ $103 \%$ for $\mathrm{Cu}, \mathrm{Ni}$, and $\mathrm{Cr}$. This indicates that the production of the generated gas and filter fly ash may be underestimated, because the high volatility may have resulted in a higher proportion of metals escaping from the furnace. Besides, incineration exhibits a lower metal recovery rate than pyrolysis and gasification processes. Part of the metals may be adsorbed or bounded by the bed materials, which will be sieved from the bottom ash and missed. Because the particle size of the incineration bottom ash is much smaller due to more thorough decomposition of the feedstock, an elevated proportion of metals will thus be excluded from the results.

Comparing the results from a tubular furnace and a fluidized bed, a similar transfer tendency of heavy metals is obtained. Generally, the volatility of target metals in decreasing order is $\mathrm{Cd}>\mathrm{Pb}>\mathrm{Zn}>\mathrm{Cu}>\mathrm{Ni}$ and $\mathrm{Cr}$ (the volatility of $\mathrm{Ni}$ and $\mathrm{Cr}$ is comparable in the analyzed temperature ranges). The experimental observations accord well with the thermodynamic equilibrium results. Tubular furnace is effective to reflect the evaporation of metals, whereas fluidized bed further reveals the effect of several factors, such as flue gas condensation and entrainment, on the distribution of metals over different ash fractions. Nevertheless $\mathrm{Pb}$ vaporization behaves differently from the two reactors. This may be attributed to the enhanced metalmatrix reaction as analyzed from the thermodynamic simulation, which emphasizes the influence of incinerator type on the transfer of metals. Overall, during MSW thermal treatment processes, parameters determining the partitioning of heavy metals can be summarized as (i) metal speciation, which depends primarily on the redox atmosphere, temperature, and presence of alkalis, chloride, sulfur, and mineral substances; (ii) system characteristics, such as furnace type and working temperature of the cyclone; (iii) mechanical entrainment of particles caused by gas velocity.

A key aspect to optimize the MSW thermal techniques will therefore be focused on reducing the environmental impact of the contaminated ashes. To improve the quality of residues, methods should be proposed aiming at concentrating most of the heavy metals in a tiny ash fraction and recycling the remainder of the ashes safely as secondary materials. ${ }^{40,42}$ Practices have proven that the typical operating temperature of gasification is $\sim 700{ }^{\circ} \mathrm{C},{ }^{43}$ lower than direct MSW incineration at ca. $850^{\circ} \mathrm{C}$. Consulting the experimental data from this study, most of the less-volatile metals, such as $\mathrm{Cu}, \mathrm{Ni}$, and $\mathrm{Cr}$, are immobilized under the working condition of gasification. It indicates the recycling potential of the gasification bottom ash. Studies have proven that via the gasification-melting process, ${ }^{2}$ metals could be separated and recovered from the residues. The melting slag is stable and contains few harmful heavy metals, which could be reused as road and construction material. Realizing these advantages, more in-depth investigation is necessary to develop gasification as a potential optimum for the current MSW incineration method.

\section{CONCLUSIONS}

The partitioning of heavy metals during S-MSW pyrolysis, gasification, and incineration are investigated. Tubular furnace tests show that a reductive atmosphere promotes the evaporation of $\mathrm{Cd}$ and $\mathrm{Zn}$ but inhibits the volatilization of $\mathrm{Pb}, \mathrm{Cu}, \mathrm{Ni}$, and $\mathrm{Cr}$. Thermodynamic equilibrium calculation reveals that the metal speciation differs a lot under redox atmosphere. Metals are alternatively reduced to elemental form or sulfide under reducing conditions. In the case of oxidizing conditions, oxides are the dominant species because of the preferential reaction of chloride with alkalis. Fluidized-bed results exhibit a quite similar changed tendency with that of the tubular furnace. However, $\mathrm{Pb}$ behaved oppositely due to the formation of stable metal-matrix compounds. Consulting the metal concentration of the fractioned cyclone ash, most of the vaporized heavy metals are condensed upon cooling at the working temperature of the cyclone $\left(350-600{ }^{\circ} \mathrm{C}\right)$; however, entrainment is also a determining factor for the transfer of lessvolatile metals under reductive atmosphere. $\mathrm{Cd}$ and $\mathrm{Pb}$ are volatile and enriched in the filter ash; thus, effective flue gas cleaning is essential for emission control. Gasification traps more of the less-volatile metals in the bottom ash; their recycling potential should be of concern to better develop heavy metal control strategies.

\section{AUTHOR INFORMATION}

\section{Corresponding Author}

*Tel.: +86-0571-87952687; Fax: +86-0571-87952438; E-mail: chiyong@zju.edu.cn.

\section{Notes}

The authors declare no competing financial interest.

\section{ACKNOWLEDGMENTS}

This project is supported by the National Basic Research Program of China (no. 2011CB201506), the National Natural 
Science Foundation of China (no. 51276168), and the Program of Introducing Talents of Discipline to University (B08026).

\section{REFERENCES}

(1) Council of European Communities. Council Directive 91/156/ EEC of 18 March 1991 amending Directive 75/442/EEC on waste; European Commission: Brussels, 1991.

(2) Arena, U.; Di Gregorio, F. Element partitioning in combustionand gasification-based waste-to-energy units. Waste Manage. 2013, 33 (5), $1142-1150$

(3) Chinese Statistics Yearbook Compiling Committee. Chinese statistics yearbook 2013; Chinese Statistics Press: Beijing, 2013.

(4) General Office of the State Council. The National Twelfth Fiveyear Plan on the construnction of urban solid waste safety disposal facilities; General Office of the State Council: Beijing, 2012.

(5) Weber, R.; Hagenmaier, H. Mechanism of the formation of polychlorinated dibenzo-p-dioxins and dibenzofurans from chlorophenols in gas phase reactions. Chemosphere 1999, 38 (3), 529-549.

(6) Arena, U. Process and technological aspects of municipal solid waste gasification. A review. Waste Manage. 2012, 32 (4), 625-639.

(7) Singh, A.; Sharma, R. K.; Agrawal, M.; Marshall, F. M. Health risk assessment of heavy metals via dietary intake of foodstuffs from the wastewater irrigated site of a dry tropical area of India. Food Chem. Toxicol. 2010, 48 (2), 611-619.

(8) Nzihou, A.; Stanmore, B. The fate of heavy metals during combustion and gasification of contaminated biomass-A brief review. J. Hazard. Mater. 2013, 256-257, 56-66.

(9) Olie, K.; Addink, R.; Schoonenboom, M. Metals as catalysts during the formation and decomposition of chlorinated dioxins and furans in incineration processes. J. Air Waste Manage. Assoc. 1998, 48 (2), 101-105.

(10) Lu, S.; Du, Y.; Zhong, D.; Zhao, B.; Li, X.; Xu, M.; Li, Z.; Luo, Y.; Yan, J.; Wu, L. Comparison of trace element emissions from thermal treatments of heavy metal hyperaccumulators. Environ. Sci. Technol. 2012, 46 (9), 5025-5031.

(11) Saffarzadeh, A.; Shimaoka, T.; Motomura, Y.; Watanabe, K. Characterization study of heavy metal-bearing phases in MSW slag. J. Hazard. Mater. 2009, 164 (2), 829-834.

(12) Zhang, H.; He, P. J.; Shao, L. M. Fate of heavy metals during municipal solid waste incineration in Shanghai. J. Hazard. Mater. 2008, 156 (1), 365-373.

(13) Belevi, H.; Langmeier, M. Factors determining the element behavior in municipal solid waste incinerators. 2. Laboratory experiments. Environ. Sci. Technol. 2000, 34 (12), 2507-2512.

(14) De Boom, A.; Degrez, M. Belgian MSWI fly ashes and APC residues: A characterisation study. Waste Manage. 2012, 32 (6), 11631170.

(15) Huang, Q.; Cai, X.; Alhadj Mallah, M. M.; Chi, Y.; Yan, J. Effect of $\mathrm{HCl} / \mathrm{SO}_{2} / \mathrm{NH}_{3} / \mathrm{O}_{2}$ and mineral sorbents on the partitioning behaviour of heavy metals during the thermal treatment of solid wastes. Environ. Technol. 2014, 1-7.

(16) Zhang, Y.; Chen, Y.; Meng, A.; Li, Q.; Cheng, H. Experimental and thermodynamic investigation on transfer of cadmium influenced by sulfur and chlorine during municipal solid waste (MSW) incineration. J. Hazard. Mater. 2008, 153 (1), 309-319.

(17) Wang, K. S.; Chiang, K. Y.; Lin, S. M.; Tsai, C. C.; Sun, C. J. Effects of chlorides on emissions of toxic compounds in waste incineration: study on partitioning characteristics of heavy metal. Chemosphere 1999, 38 (8), 1833-1849.

(18) Belevi, H.; Moench, H. Factors determining the element behavior in municipal solid waste incinerators. 1. Field studies. Environ. Sci. Technol. 2000, 34 (12), 2501-2506.

(19) Sun, L.; Abanades, S.; Lu, J.; Flamant, G.; Gauthier, D. Volatilization of heavy metals during incineration of municipal solid wastes. J. Environ Sci. (China) 2004, 16 (4), 635-639.

(20) Yu, J.; Sun, L.; Xiang, J.; Hu, S.; Su, S.; Qiu, J. Vaporization of heavy metals during thermal treatment of model solid waste in a fluidized bed incinerator. Chemosphere 2012, 86 (11), 1122-1126.
(21) Wu, M. H.; Lin, C. L.; Zeng, W. Y. Effect of waste incineration and gasification processes on heavy metal distribution. Fuel Process. Technol. 2014, 125, 67-72.

(22) Jakob, A.; Stucki, S.; Kuhn, P. Evaporation of heavy metals during the heat treatment of municipal solid waste incinerator fly ash. Environ. Sci. Technol. 1995, 29 (9), 2429-2436.

(23) Abanades, S.; Flamant, G.; Gagnepain, B.; Gauthier, D. Fate of heavy metals during municipal solid waste incineration. Waste Manage. Res. 2002, 20 (1), 55-68.

(24) Elled, A. L.; Amand, L. E.; Eskilsson, D. Fate of zinc during combustion of demolition wood in a fluidized bed boiler. Energy Fuels 2008, 22 (3), 1519-1526.

(25) Enestam, S.; Backman, R.; Makela, K.; Hupa, M. Evaluation of the condensation behavior of lead and zinc in BFB combustion of recovered waste wood. Fuel Process. Technol. 2013, 105, 161-169.

(26) Patumsawad, S.; Cliffe, K. R. Experimental study on fluidised bed combustion of high moisture municipal solid waste. Energy Convers. Manage. 2002, 43 (17), 2329-2340.

(27) Dong, J.; Chi, Y.; Zou, D.; Fu, C.; Huang, Q.; Ni, M. Comparison of municipal solid waste treatment technologies from a life cycle perspective in China. Waste Manage. Res. 2014, 32 (1), 1323.

(28) United States Environmental Protection Agency. Method 29Determination of Metals Emissions from Stationary Sources; Office of Air Quality Planning and Stardards: Washington, DC, 1996.

(29) Xiao, G. Study on MSW fluidized-bed gasification and swirlmelting technology. Ph.D thesis, Zhejiang University, Hangzhou, China, 2006.

(30) Elled, A.-L.; Åmand, L.-E.; Eskilsson, D. Fate of zinc during combustion of demolition wood in a fluidized bed boiler. Energy Fuels 2008, 22 (3), 1519-1526.

(31) Šyc, M.; Pohořelý, M.; Jeremiáš, M.; Vosecký, M.; Kameníková, P.; Skoblia, S.; Svoboda, K.; Punčochár, M. Behavior of heavy metals in steam fluidized bed gasification of contaminated biomass. Energy Fuels 2011, 25 (5), 2284-2291.

(32) Liu, J.; Falcoz, Q.; Gauthier, D.; Flamant, G.; Zheng, C. Volatilization behavior of $\mathrm{Cd}$ and $\mathrm{Zn}$ based on continuous emission measurement of flue gas from laboratory-scale coal combustion. Chemosphere 2010, 80 (3), 241-247.

(33) Abanades, S.; Flamant, G.; Gauthier, D. Kinetics of heavy metal vaporization from model wastes in a fluidized bed. Environ. Sci. Technol. 2002, 36 (17), 3879-3884.

(34) Verhulst, D.; Buekens, A.; Spencer, P. J.; Eriksson, G. Thermodynamic behavior of metal chlorides and sulfates under the conditions of incineration furnaces. Environ. Sci. Technol. 1995, 30 (1), $50-56$.

(35) Zhong, D. X.; Zhong, Z. P.; Wu, L. H.; Xue, H.; Song, Z. W.; Luo, Y. M. Thermal characteristics and fate of heavy metals during thermal treatment of Sedum plumbizincicola, a zinc and cadmium hyperaccumulator. Fuel Process. Technol. 2015, 131, 125-132.

(36) Basu, P. Combustion of coal in circulating fluidized-bed boilers: a review. Chem. Eng. Sci. 1999, 54 (22), 5547-5557.

(37) Folgueras, M. B.; Díaz, R. M.; Xiberta, J.; Alonso, M. Effect of inorganic matter on trace element behavior during combustion of coalsewage sludge blends. Energy Fuels 2007, 21 (2), 744-755.

(38) van Lith, S. C.; Jensen, P. A.; Frandsen, F. J.; Glarborg, P. Release to the gas phase of inorganic elements during wood combustion. Part 2: Influence of fuel composition. Energy Fuels 2008, 22 (3), 1598-1609.

(39) Liu, J.; Fu, J.; Ning, X.; Sun, S.; Wang, Y.; Xie, W.; Huang, S.; Zhong, S. An experimental and thermodynamic equilibrium investigation of the $\mathrm{Pb}, \mathrm{Zn}, \mathrm{Cr}, \mathrm{Cu}, \mathrm{Mn}$ and $\mathrm{Ni}$ partitioning during sewage sludge incineration. J. Environ. Sci. 2015, 35, 43-54.

(40) Vervaeke, P.; Tack, F.; Navez, F.; Martin, J.; Verloo, M.; Lust, N. Fate of heavy metals during fixed bed downdraft gasification of willow wood harvested from contaminated sites. Biomass Bioenergy 2006, 30 (1), 58-65. 
(41) Jung, C.; Matsuto, T.; Tanaka, N.; Okada, T. Metal distribution in incineration residues of municipal solid waste (MSW) in Japan. Waste Manage. 2004, 24 (4), 381-391.

(42) Narodoslawsky, M.; Obernberger, I. From waste to raw material一the route from biomass to wood ash for cadmium and other heavy metals. J. Hazard. Mater. 1996, 50 (2), 157-168.

(43) Arena, U.; Di Gregorio, F. Gasification of a solid recovered fuel in a pilot scale fluidized bed reactor. Fuel 2014, 117, 528-536. 